\title{
ANALISA NILAI TANDA-TANDA VITAL PASIEN GAGAL JANTUNG
}

\author{
Rizka Febtrina ${ }^{1)}$, Eka Malfasari ${ }^{2)}$ \\ ${ }^{1,2}$ Program Studi Profesi Ners, STIKes Payung Negeri Pekanbaru \\ email: rizka.febtrina@payungnegeri.ac.id
}

Diterima : September 2018, Diterbitkan : Desember 2018

\begin{abstract}
Heart failure is a major cause of death in the world and Indonesia. Patients with heart failure need monitoring of the state of circulation, one of which is vital signs. Vital signs consist of examination of blood pressure, pulse frequency, respiratory frequency and MAP. The purpose of this study was to determine the description of vital signs in patients with heart failure. This research uses a descriptive method. This study involved as many as 50 respondents of heart failure patients. The instrument used to measure blood pressure was measured using sphygmomanometer, heart rate and respiratory frequency were measured by direct counting by the researcher. Data analysis used is univariate test. The results of this study indicate that the average systolic blood pressure in heart failure patients is $133.58 \mathrm{mmHg}$ and diastolic blood pressure in heart failure patients is 86.5 $\mathrm{mmHg}$. The average MAP for heart failure patients is $101.6 \mathrm{mmHg}$. The average rate of heart failure patients is 91.7 times / minute. The average respiratory frequency in heart failure patients is 23.24 times / minute. The conclusion of this study is that vital signs in heart failure patients are in the normal range.
\end{abstract}

Keywords: vital signs, heart failure

\begin{abstract}
Abstrak
Gagal jantung merupakan penyebab kematian yang utama di dunia maupun Indonesia. Pasien gagal jantung memerlukan pemantauan terhadap keadaan sirkulasinya, salah satu nya adalah tanda- tanda vital. Tanda - tanda vital terdiri dari pemeriksaan tekanan darah, frekuensi nadi, frekuensi pernafasan dan MAP. Tujuan penelitian ini untuk mengetahui gambaran tandatanda vital pada pasien gagal jantung. Penelitian ini menggunakan metode deskriptif. Penelitian ini melibatkan sebanyak 50 responden pasien gagal jantung. Instrumen yang digunakan untuk mengukur tekanan darah diukur dengan menggunakan spigmomanometer, denyut jantung dan frekuensi pernafasan diukur dengan penghitungan langsung oleh peneliti. Analisa data yang digunakan adalah uji univariat. Hasil penelitian ini menunjukkan bahwa rata - rata tekanan darah sistolik pasien gagal jantung sebesar $133.58 \mathrm{mmHg}$ dan tekanan darah diastolik pasien gagal jantung sebesar $86.5 \mathrm{mmHg}$. Rata - rata MAP pasien gagal jantung adalah $101.6 \mathrm{mmHg}$. Rata - rata nadi pasien gagal jantung adalah 91.7 kali/menit. Rata- rata frekuensi pernafasan pada pasien gagal jantung adalah 23.24 kali/menit. Kesimpulan dari penelitian ini bahwa tanda-tanda vital pada pasien gagal jantung berada dalam rentang normal.
\end{abstract}

Kata Kunci: tanda- tanda vital, gagal jantung 


\section{PENDAHULUAN}

\section{Penyakit}

kardiovaskuler

merupakan penyebab utama kematian pada beberapa dekade terakhir di dunia. pada tahun 2004 penyakit kardiovaskuler penyebab 17 juta kematian dan lebih dari 151 juta menyebabkan kehilangan kemampuan dalam aktifitas sehari - hari. Angka harapan hidup yang semakin meningkat, mengakibatkan prevalensi penyakit gagal jantung semakin meningkat. Hal ini disebabkan semakin banyaknya lansia yang mempunyai hipertensi mempertinggi kemungkinan terkena gagal jantung. Selain itu semakin membaiknya angka keselamatan postinfark pada usia pertengahan, menyebabkan meningkatnya jumlah lansia dengan resiko mengalami gagal jantung (Bonow, Mann, Zipes \& Libby, 2012).

Jumlah penderita gagal jantung di Indonesia belum diketahui dengan pasti tetapi dari hasil Riset Kesehatan Nasional (Riskesdas) pada tahun 2007 menyatakan bahwa kematian akibat penyakit tidak menular khususnya penyakit jantung dan pembuluh darah terus meningkat menjadi 59,5\% pada tahun 2007 dibandingkan dengan tahun 1995 hanya sebesar 41,7\%. Prevelensi penyakit jantung di Indonesia sebesar 7, 2\% dan menempati urutan 3 besar penyebab kematian setelah stroke dan hipertensi. Hasil Riskesdas 2007 juga menyatakan bahwa beberapa faktor resiko penyakit jantung dan pembuluh darah antara lain obesitas, DM, makan makanan yang asin dan berlemak, kurang sayur dan buah, kurang aktifitas fisik, perokok dan peminum alkohol (Keputusan Menteri Kesehatan Republik Indonesia, 2009).

Gagal jantung merupakan penyakit kronik yang sering dikaitkan dengan tingginya mortalitas, kejadian rawat ulang yang tinggi, menurunnya kualitas hidup, berbagai komorbit, dan regimen pengobatan yang kompleks (Heart Failure Society of America, 2010). Gejala yang dirasakan pasien HF mencakup dispnea, Ortopnea, Paroximal Nocturnal Dysnea
(PND), Dyspnea on Effort (DOE), edema, penurunan haluaran urin, kelemahan (Price \& Wilson, 2006; Lemon \& Burke, 2008; Smeltzer \& Bare, 2010).

Dampak yang ditimbulkan dari gagal jantung sangat mempengaruhi terhadap aktifitas sehari-hari. Hal ini karena gagal jantung mengakibatkan perasaan sulit bernafas karena adanya tahanan aliran udara dan kongesti vaskular paru, denyut jantung akan meningkat sebagai respon terhadap rangsangan saraf simpatik. Tekanan darah pada pasien gagal jantung juga akan meningkat, hal ini terjadi karena kompensasi vasokontriksi arteri sebagai upaya mempertahankan penurunan curah jantung. Kompensasi yang dilakukan dalam mempertahankan curah jantung juga memiliki efek yang negatif sehingga akan memperberat kerja jantung dan memperburuk derajat gagal jantung (Price \& Wilson, 2006; LeMon \& Burke, 2008).

Pemeriksaan TTV merupakan pemeriksaan non invasif yang sering dilakukan oleh perawat. pemeriksaan TTV terdiri dari pemeriksaan tekanan darah, frekuensi denyut nadi, frekuensi pernafasan dan suhu. Perawat sebagai bagian dari tim kesehatan harus dapat menganalisa nilai dari tanda-tanda vital (TTV) sehingga dapat memberikan intervensi yang tepat pada pasien gagal jantung.

Penelitian ini bertujuan untuk mengalisa gambaran tanda - tanda vital pasien gagal jantung.

\section{METODE PENELITIAN}

Penelitian ini akan menggunakan desain deskriptif. Sampel pada penelitian ini berjumlah 50 responden. Penelitian dilakukan di ruang flamboyan RSUD Arifin Achmad Provvinsi Riau. Variabel tanda - tanda vital seperti tekanan darah diukur dengan menggunakan spigmomanometer, denyut jantung dan frekuensi pernafasan diukur dengan penghitungan langsung oleh peneliti. 
Uji statistik dalam penelitian ini untuk melihat gambaran TTV pada pasien gagal jantung menggunakan uji univariat. Penelitian ini sudah mendapatkan lulus uji etik dari komite etik Fakultas Kedokteran Universitas Riau

\section{HASIL DAN PEMBAHASAN}

Karakteristik responden dalam penelitian ini dapat dilihat pada tabel 1 .

Tabel 1. Distribusi frekuensi responden berdasarkan usia, lama didiagnosa HF dan lama rawat

\begin{tabular}{lccc}
\hline \multicolumn{1}{c}{ Variabel } & $\begin{array}{c}\text { Mean (Min- } \\
\text { Max) }\end{array}$ & Median & SD \\
\hline Usia & $48.98(18-73)$ & 48 & 13.11 \\
Lama di & $2.48(1-8)$ & 2 & 1.59 \\
diagnosa HF & & & \\
Lama rawat & $3.38(1-29)$ & 2 & 4.23 \\
\hline
\end{tabular}

Berdasarkan tabel diatas dapat dilhat bahwa rata - rata pasien gagal jantung yang dirawat berusia 49 tahun (usia termuda 18 tahun dan yang tertua 73 tahun). Usia yang semakin menua menjadikan tekanan darah meningkat hal ini disebabkan karena perubahan struktur dan fungsional pada sistem pembuluh perifer. Perubahan yang terjadi seperti aterosklerosis, kehilangan elastisitas jaringan penghubung dan menurunnya relaksasi otot polos pembuluh darah, yang pada gilirannya menurunkan kemampuan distensi dan daya regang pembuluh darah. Konsekuensinya, aorta dan arteri besar berkurang kemampuannya dalam mengakomodasi volume darah yang dipompa oleh jantung (volume sekuncup), mengakibatkan penurunan curah jantung dan peningkatan tahanan perifer. Perubahan tersebut juga mengakibatkan kontraktilitas miokardium. Salah satu perubahan yang disebabkan karena usia adalah respon fisik dan stres emosional menurunkan curah jantung dan volume sekuncup yang disebabkan oleh penurunan kontraktilitas dan respon denyut jantung meningkat akibat stres (Lewis et al, 2011; Sherwood, 2012).
Rata - rata pasien gagal jantung yang dirawat sudah di diagnosa cgagal jantung selama 2.48 tahun. pasien gagal jantung sering merasa bahwa tidak memerlukan perawatan jika tidak ada tanda dan gejala yang muncul. Padahal ketika seseorang sudah di diagnosa terjadinya kerusakan dari fungsi jantung untuk memompakan darah maka fungsi tersebut harus dijaga dengan melakukan perubahan gaya hidup dan minum obat obatan secara teratur. Seiring dengan meningkatnya lama terdiagnosis gagal jantung maka keparahan gagal jantung juga akan meningkat.

Lama rawat pasien rata - rata selama 3 hari. Lama rawat pasien dalam menjalani perawatan gagal jantung mendapatkan perhatian yang serius, hal ini dikarenakan akan dapat mempenaruhi kualitas hidup pasien gagal jantung, resiko kejadian dimasa depan serta tingkat kecemasan pasien gagal jantung (Djaya, Nasution, \& Antono, 2015).

Tabel 2 Distribusi frekuensi responden berdasarkan jenis kelamin, pendidikan, pekerjaan dan derajat gagal jantung

\begin{tabular}{|c|c|c|c|}
\hline $\begin{array}{l}\mathbf{N} \\
\mathbf{0}\end{array}$ & Variabel & $\begin{array}{c}\text { Jumlah } \\
\text { (n) }\end{array}$ & $\begin{array}{c}\text { Persenta } \\
\text { se }(\%)\end{array}$ \\
\hline \multirow[t]{3}{*}{1} & Jenis Kelamin & & \\
\hline & Laki - laki & 28 & 56 \\
\hline & Perempuan & 22 & 44 \\
\hline \multirow[t]{5}{*}{2} & Pendidikan & & \\
\hline & SD & 13 & 26 \\
\hline & SMP & 9 & 18 \\
\hline & SMA & 26 & 52 \\
\hline & PT & 2 & 4 \\
\hline \multirow[t]{5}{*}{3} & Pekerjaan & & \\
\hline & Wiraswasta & 9 & 18 \\
\hline & PNS & 2 & 4 \\
\hline & IRT & 16 & 32 \\
\hline & $\begin{array}{l}\text { Lain-lain } \\
\text { (Pedagang, Petani, } \\
\text { Supir, Buruh) }\end{array}$ & 23 & 46 \\
\hline \multirow[t]{4}{*}{4} & Derajat gagal jantung & & \\
\hline & Derajat II & 24 & 48 \\
\hline & Derajat III & 18 & 36 \\
\hline & Derajat IV & 8 & 16 \\
\hline
\end{tabular}

Berdasarkan tabel 2 diketahui bahwa pasien gagal jantung yang berjenis kelamin laki - laki yaitu sebanyak 28 orang $(56 \%)$, sedangkan perempuan 
berjumlah 22 orang (44\%). Jenis kelamin juga mempengaruhi terhadap status kardiovaskuler seseorang. Laki-laki dan perempuan memiliki resiko yang berbeda untuk terserang penyakit jantung. Hal ini didasarkan bahwa laki-laki mempunyai resiko disfungsi sistolik lebih besar dibanding perempuan, sedangkan pada perempuan disfungsi diastolik lebih sering terjadi (Lewis et al, 2011).

Pendidikan responden paling banyak adalah SMA sebanyak 26 orang $(52 \%)$ dan hanya 2 orang yang berpendidikan tinggi (4\%). Kejadian gagal jantung tidak erat hubungannya dengan tingkat pendidikan. Tingkat pendidikan yang semakin tinggi akan membuat seseorang mudah untuk menerima informasi dan mengelola gaya hidupnya, termasuk pencegaham maupun perawatan penyakitnya (Harigustian, 2017).

Pasien gagal jantung paling banyak bekerja sebagai pedagang, petani, supir dan buruh yaitu sebanyak 23 orang (46\%) dan bekerja sebagai PNS sebanyak 2 orang (4\%). Gagal jantung tidak memandang latar belakang pekerjaan. Pekerjaan yang berat dan terus menerus dan kurang istirahat dapat dapat meningkatkan beban kerja jantung. Jika ini berlangsung terus menerus dan tidak dikelola dengan baik maka akan dapat menyebabkan peningkatan beban kerja jantung yang dapat berakhir dengan gagal jantung (Harigustian, 2017).

Pasien paling banyak berada pada derajat II yaitu sebanyak 24 orang (48\%) dan terdapat 8 orang (16\%) pada derajat IV. Derajat penyakit jantung merujuk pada NYHA dibagi menjadi 4 kelas. Kelas atau derajat keparahan pasien gagal jantung tersebut berdasarkan kemampuan individu dalam melakukan fungsi kehidupan aktifitas sehari - hari. Pembagian kelas tersebut dimulai dari ringan sampai terberat. Peningkatan derajat gagal jantung akan memperlihatkan penurunan kemampuan pemenuhan fungsi fisik (Lewis et al, 2011).
Tabel 3. Distribusi frekuensi responden berdasarkan tanda-tanda vital

\begin{tabular}{lcccc}
\hline Variabel & Mean & $\begin{array}{c}\text { Media } \\
\text { n }\end{array}$ & SD & $\begin{array}{c}\text { Min - } \\
\text { Maks }\end{array}$ \\
\hline TDS & 133.58 & 130 & 20.4 & $100-172$ \\
TDD & 86.5 & 90 & 13.5 & $60-120$ \\
MAP & 101.6 & 100 & 16.2 & $50-137$ \\
Nadi & 91.7 & 93 & 10.8 & $64-124$ \\
Pernafasan & 23.24 & 23.50 & 3 & $18-28$ \\
\hline
\end{tabular}

Tanda - tanda vital merupakan cara yang cepat dan efisien untuk memantau kondisi pasien atau mengidentifikasi masalah dan mengevaluasi respon pasien terhadap intervensi. Tanda-tanda vital atau tanda-tanda dasar meliputi suhu, denyut nadi, pernapasan dan tekanan darah. Sebagai indikator dari status kesehatan, ukuran-ukuran ini menandakan keefektifan sirkulasi, respirasi, fungsi saraf dan endokrin tubuh, karena sangat penting maka disebut tanda vital. Pada pasien gagal jantung pemantauan tanda - tanda vital meruapakn tindakan yang harus dilakukan secara berkala untuk dapat menilai keadaan jantung.

Tabel 3 memperlihatkan bahwa rata - rata tekanan darah sistolik (TDS) pasien gagal jantung sebesar 133.58 $\mathrm{mmHg}$ dan tekanan darah diastolik (TDD) pasien gagal jantung sebesar $86.5 \mathrm{mmHg}$ Tekanan darah merupakan indikator dalam kesehatan kardiovaskuler. Pada pasien gagal jantung tekanan darah yang tinggi akan berakibat meeningkatnya beban jantung, sedangkan tekanan darah yang rendah mengindikasikan kerja jantung yang gagal.

Gagal jantung disebabkan karena disfungsi dari saraf simpatis dan peningkatan aktifitas saraf simpatis dilaporkan merupakan salah satu yang dapat menyebabkan prognosis buruk pada pasien gagal jantung (Kishi, 2012). Penurunan curah jantung akan mengaktifkan sistem saraf simpatis. Rangsangan ini akan membuat jantung dan pembuluh darah berespin mengeluarkan epineprin dan norefineprin. Norefineprin menstimulasi reseptor $\beta 1$ sehingga meningkatkan detak jantung dan 
kontraktilitas. Norefineprin juga menyebabkan vasokontriksi arteri dan vena serta meningkatkan aliran balik vena. Konstriksi arteri lama - kelamaan akan meningkatkan afterload, sehingga terjadi resistensi pemompaan jantung. Sejalan dengan peningkatan tersebut maka ventrikel kiri harus bekerja lebih berat, hal ini tentu saja akan semakin memperburuk keadaan (LeMon \& Burke, 2008; Kishi, 2012).

Rata - rata MAP pasien gagal jantung adalah $101.6 \mathrm{mmHg}$. Tekanan arteri rata-rata merupakan tekanan arteri rata-rata selama siklus jantung. MAP merupakan cerminan dari resistensi perifer dan volume rata-rata dalam arteri. MAP dapat mempresentasikan rata - rata tekanan darah pada jaringan tubuh selama satu siklus jantung (Darovic, 2002).

MAP normal adalah $70-90$ mmHg. Nilai MAP harus dipertahankan diatas $60 \mathrm{mmHg}$, jika nilai kurang dari 60 $\mathrm{mmHg}$ maka perfusi ke otak, arteri koroner dan ginjal akan terganggu. Nilai MAP diatas $100 \mathrm{mmHg}$ juga merupakan situasi yang tidak baik, hal ini menandakan tekanan pada pembuluh darah sangat tinggi, sehingga meningkatkan resiko terjadinya kerusakan vaskular dan ruptur kapiler (Lewis et al, 2011; Black \& Hawks, 2005).

Tabel 3 juga menunjukkan rata rata nadi pasien gagal jantung adalah 91.7 kali/menit. Denyut nadi adalah frekuensi irama denyut/detak jantung yang dapat dipalpasi dipermukaan kulit pada tempattempat tertentu pada tubuh. Pada jantung manusia normal, tiap-tiap denyut berasal dari nodus SA. Nadi merupakan salah satu indikator status sirkulasi (Waugh \& Grant, 2006; Potter \& Perry, 2006; Sherwood, 2011).

Menurut Ganong (2008) saraf otonom simpatis membuat vasokontriksi arteriol dan vena serta meningkatkan frekunesi denyut jantung dan isi sekuncup melepaskan muatan dengan cara tonik, dan tekanan darah disesuaikan dengan variasi kecepatan muatan tonik ini. Aktivitas simpatis dan parasimpatis pada jantung dan pembuluh darah tidak terlepas dari pengaruh aktivitas hormon epineprin dan norepineprin (adrenalin). Peningkatan sekresi hormon ini akan menginduksi dan mengeksitasi saraf simpatis untuk melakukan vasokontriksi sehingga terjadi peningkatan frekuensi denyut jantung yang diikuti oleh peningkatan tekanan darah.

Rerata frekuensi pernafasan pada responden pasien gagal jantung adalah $23.24 \mathrm{kali} / \mathrm{menit}$. Penurunan curah jantung mengakibatkan peningkatan frekuensi nafas, hal ini terjadi sebagai upaya kompensasi karena meningkatnya kebutuhan oksigen jaringan. Pada gagal jantung terjadi peningkatan kerja pernafasan akibat kongesti vaskular paru yang mengurangi kelenturan paru, hal ini mengakibatkan meningkatnya tekanan aliran udara sehingga mengakibatkan dispnea. Aktifitas akan memperberat keadaan ini, selain itu peningkatan frekuensi pernafasan juga dipengaruhi oleh aktifitas saraf simpatis.

Peneliti berasumsi bahwa rata- rata nilai TTV pasien gagal jantung yang menjadi responden pada penelitian ini berada dalam rentang normal. Hal ini mungkin dipengaruhi oleh penggunaan obat- obatan non farmakologis yang diperoleh selama perawatan dirumah sakit. Hal ini mungkin menjadi kelemahan pada penelitian ini karena tidak mempertimbangkan variabel pengganggu.

\section{SIMPULAN}

Hasil penelitian ini menyimpulkan bahwa tanda-tanda vital pada pasien gagal jantung berada dalam rentang normal. Hal ini harus dipertahankan untuk tetap menjaga agar beban kerja jantung tidak semakin berat. Penelitian ini merekomendasikan untuk dapat memberikan intervensi mandiri keperawatan dalam menjaga kestabilan tanda-tanda vital pada pasien jantung. 
UCAPAN TERIMA KASIH

Peneliti mengucapkan terima kasih kepada Direktur Penelitian dan Pengabdian Masyarakat Direktorat Jendral Pendidikan Tinggi Republik Indonesia, Lembaga Layanan Pendidikan Tinggi Sepuluh (L2 Ditkti X) regional wilayah Sumatra barat, Riau, Jambi dan Kepulauan Riau, Ketua STIKes Payung Negeri Negeri Pekanbaru, Ketua Lembaga Penelitian dan Pengabdian Masyarakat (LPPM) STIKes Payung Negeri Pekanbaru, serta RSUD Arifin Achamd Provinsi Riau yang telah memfasilitasi penelitian ini.

\section{DAFTAR PUSTAKA}

Bonow, R. O., Mann, D. L., Zipes, D. P., \& Libby, P. (2011). Braunwald's Heart Disease: A Textbook of Cardiovascular Medicine: Elsevier Health Sciences.

Black, J.W., \& Hawks, J.H. (2009). Medical surgical nursing : clinical managenent for positive outcome, vol 2. 8ed. Singapore: Elsevier Saunders.

Darovic, G. O. (2002). Hemodynamic monitoring:invasive and noninvasive clinical application (3 $\left.{ }^{\mathrm{rd}} \mathrm{Ed}\right)$. USA: Saunders.

Djaya, K. H., Nasution, S. A., \& Antono, D. (2015). Gambaran Lama Rawat dan Profil Pasien Gagal Jantung di Rumah Sakit Cipto Mangunkusumo. Indonesia Journal of CHEST, 2(4).

Ganong, W. F. (2008). Buku ajar fisiologi kedokteran, ed 22. Jakarta: EGC.

Harigustian, Y. (Universitas M. yogyakarta). (2017). Gambaran Karakteristik Pasien Gagal Jantung di Rumah Sakit PKU Muhammadiyah Gemping Sleman. Universitas Muhammadiyah
Yogyakarta.

https://doi.org/10.18196/ijnp.1152

Heart Failure Society of, A. (2010). Executive Summary: HFSA 2010 Comprehensive Heart Failure Practice Guideline. Journal of Cardiac Failure, 16(6), 475-539. doi:

http://dx.doi.org/10.1016/j.cardfail. $\underline{2010.04 .005}$

Keputusan Menteri Kesehatan Indonesia. (2009). Pedoman pengendalian penyakit jantung dan pembuluh darah, No. 854/MENKES/SK/IX/2009.

Diunduh dari http://www.hukor.depkes.go.id/up prod_kepmenkes/KMK\%20No.\%2 0854\%20Tahun\%202009\%20ttg\% 20Pengendalian\%20Penyakit $\% 20 \mathrm{~J}$ antung.pdf

Kishi, T. (2012). Heart failure as an autonomic nervous system dysfunction. Journal of cardiology (2012) 59, 117 - 122. Diunduh dari http://www.sciencedirect.com/scien ce/article/pii/S1054880711001529

LeMone, P., \& Burke, K. (2008). Medical Surgical Nursing: critical thinking in client care. 4ed.vol 2. USA: Pearson International Edition.

Lewis, S. H., Dirksen, S. R., Heitkemper, M. M., Bucher, L, \& Camera, I. M. (2011). Medical surgical nursing: assessment and management of clinical problems, vol 1, 8ed. St. Louis: Elsevier mosby.

Potter, P. A, \& Perry, A. G. (2006). Buku ajar fundamental keperawatan: konsep, proses dan praktik. Edisi 4, vol 2. Jakarta: EGC.

Price, S. A., \& Wilson, L. M. (2006). Patofisiologi; konsep klinik proses- 
proses penyakit. Edisi. 6, vol 1. Jakarta: EGC.

Sherwood, L. (2012). Fisiologi Manusia; dari sel ke sistem Ed. 6. EGC. Jakarta.

Waugh, A \& Grant, A . (2006). Anatomy and Physiology: in Health and Illness by Anne Waugh and Allison Grant $\left(10^{\text {th }}\right.$ Ed). Churchill Livingston 